Fetal Diagnosis and Therapy

\title{
Prognosis of Fetal Parenchymal Cerebral Lesions without Ventriculomegaly in Congenital Toxoplasmosis Infection
}

\author{
Ferdinand Dhombres $^{a} \quad$ Stéphanie Friszer $^{a} \quad$ Paul Maurice $^{a} \quad$ Marie Gonzales $^{b}$ \\ François Kieffer $^{c}$ Catherine Garel ${ }^{d}$ Jean-Marie Jouannic ${ }^{a}$ \\ a Sorbonne Universités, UPMC Université Paris 6, APHP, Service de Médecine Foetale, b Sorbonne Universités, \\ UPMC Université Paris 6, APHP, Unité de Foetopathologie, 'APHP, Service de Néonatologie, and dAPHP, Service de \\ Radiopédiatrie, Hôpital Armand Trousseau, Paris, France
}

\author{
Key Words \\ Congenital toxoplasmosis infection - Ultrasound . \\ Prognosis · Cerebral lesions
}

\begin{abstract}
Objective: To evaluate the neurodevelopmental and ocular outcome of a continuous retrospective series of fetal toxoplasmosis infections for which prenatal ultrasound (US) follow-up revealed abnormal cerebral findings without associated ventriculomegaly. Materials and Methods: We retrospectively reviewed all cases of proven fetal Toxoplasma gondii infection with fetal cerebral anomalies at US examination without significant ventriculomegaly $(\geq 10 \mathrm{~mm}$ ) evaluated in our center over a 5 -year period. US and magnetic resonance imaging findings were collected. The neurodevelopmental and ocular outcomes of the cases were studied. Results: Nine fetuses were included. Hyperechogenic foci of the cerebral parenchyma were isolated in five cases. Among those, four children had normal neurological development. Amblyopia was detected in on case. Hyperechogenic foci were associated with other anomalies of cerebral parenchyma in three cases among which two children had normal neurological development. Termination of pregnancy was
\end{abstract}

performed in three cases: one case within the context of severe maternal schizophrenia with isolated hyperechogenic foci, one case where hyperechogenic foci were associated with extensive lesions of the white matter, and one case for severe fetal hydrops. Conclusion: The neurological prognosis of cerebral hyperechogenic lesions without ventriculomegaly in fetal toxoplasmosis infection may be favorable. The risk of ocular damage however remains high and unpredictable in the prenatal period.

(c) 2016 S. Karger AG, Basel

\section{Introduction}

Maternal primary infection by Toxoplasma gondii during pregnancy may result in fetal infection with the potential risk of mild or severe lesions. The justification of both maternal biological systematic screening [1] and prenatal treatment still remain controversial $[2,3]$. Thus, few countries have implemented toxoplasmosis infection screening in the prenatal care for normal pregnancies. The prenatal diagnosis of toxoplasmosis is based either on maternal primary infection or on the detection of fetal anomalies on routine fetal ultrasound (US) examination.

\section{KARGER}

(c) 2016 S. Karger AG, Basel

E-Mail karger@karger.com

www.karger.com/fdt
J.-M. Jouannic

Service de Médecine Foetale, Hôpital Armand Trousseau

APHP, Université Paris 6

26 avenue A. Netter, FR-75012 Paris (France)

E-Mail jean-marie.jouannic@ aphp.fr 
The aim of prenatal diagnosis is to identify the most severe cases associated with fetal cerebral damage. Ventricular dilation is a frequent ultrasonographic sign that is easy to demonstrate. This progressive hydrocephaly is due to necrotizing lesions in the periaqueductal area and carries a poor prognosis. Other cerebral locations of the encephalopathy may exist without ventricular dilation [4]. However, there are few data on the prognosis of these cerebral parenchymal lesions.

We aimed to evaluate the neurodevelopmental and ocular outcome of a continuous retrospective series of infected fetuses for which prenatal US follow-up revealed abnormal cerebral findings without associated ventriculomegaly.

\section{Materials and Methods}

We retrospectively reviewed all cases of proven fetal $T$. gondii infection with fetal cerebral anomalies at US examination without significant ventriculomegaly $(\geq 10 \mathrm{~mm})$ evaluated in our center over a 5-year period (January 2010 to January 2015). The gestational age at maternal seroconversion was estimated by maternal serum analysis, including avidity test for IgG when required. The prenatal data collected included (1) time of maternal infection classified as first-, second- or third-trimester infection, and (2) results of PCR analysis for T. gondii in the amniotic fluid. In cases of proven fetal infection, patients received a specific treatment using pyrimethamine + sulfadiazine.

According to our protocol of prenatal follow-up in case of proven fetal toxoplasmosis infection, monthly US examinations were performed using a Voluson Expert VE8 (General Electric Medical Systems, Zipf, Austria) or an Applio unit (Toshiba, Tokyo, Japan). All US scans were performed transabdominally and the transvaginal route was not necessary in order to obtain satisfactory central nervous system evaluation. Magnetic resonance imaging (MRI) examination was performed in cases of abnormal fetal cerebral US findings on a 1.5-Tesla unit (Achieva Philips Medical Systems, Best, The Netherlands) 30-40 min following fetal sedation achieved by maternal oral administration of flunitrazepam (1 mg). Fetal brain examination was performed using a phasedarray abdominal coil, T1-weighted spin echo, spectral presaturation inversion recovery, fat-saturated sequences (693/14/2; flip angle $90^{\circ}$; matrix $256 \times 125$; field of view $320 \mathrm{~mm}$; section thickness $4 \mathrm{~mm}$; acquisition time $2 \mathrm{~min} 56 \mathrm{~s}$ ) and T2-weighted single-shot turbo spin echo sequences $\left(15,000 / 120 / 1\right.$ flip angle, $90^{\circ}$; turbo spin echo factor 102; matrix $256 \times 170$; field of view $300 \mathrm{~mm}$; section thickness $2 \mathrm{~mm}$; acquisition time $45 \mathrm{~s}$ ). In some cases, T2*- and diffusion-weighted imaging sequences were added. All prenatal imaging was reviewed by an expert radiologist (C.G.).

Postnatal evaluation included complete clinical and neurological evaluation of the neonates using the revised Brunet-Lezine scale within the first 2 weeks and every 3 months during the first year. A systematic transfontanellar US examination was performed during the first month of life. Ocular examinations, including ocular fundus examinations, were performed every 3 months during the first year and at 15, 18 and 24 months. Ocular examina-

Fetal Parenchymal Cerebral Lesions in Congenital Toxoplasmosis Infection tions were thereafter scheduled on a yearly basis. Visual acuity was assessed using Parinaud charts for children up to 3 years of age. All neonates received a specific 12 -month pyrimethamine-sulfadiazine treatment [5].

\section{Results}

Nine cases of fetal infection for toxoplasmosis with anomalies of the cerebral parenchyma and no associated ventriculomegaly were identified (table 1). Fetal infection occurred during the second trimester in six cases. In three other cases the available maternal serum did not allow to formally exclude fetal first-trimester infection based on avidity tests on IgG.

\section{Fetal Imaging Findings}

Fetal cerebral anomalies were identified by US examination at a median gestational age of $31+5$ weeks (range 24.0-34.5 weeks). In one case fetal toxoplasmosis infection was diagnosed as part of the prenatal investigation for a fetal hydrops observed during third-trimester routine scan. An US examination performed at $32+5$ weeks revealed multiple $(>10)$ echogenic nodular foci throughout the cerebral parenchyma. Hepatosplenomegaly associated with myocardial hypertrophy was also noted. Fetal hydrops worsened and termination of pregnancy (TOP) was performed at 34 weeks (case 9).

In the eight other cases, cerebral anomalies were detected within the context of a specific US follow-up for a proven infection of the fetus (PCR positive on amniotic fluid). In these cases, one or multiple echogenic nodular foci (fig. 1) were observed at third-trimester US examination (29-34 weeks) in seven cases and at 24 weeks in one case (case 3 ).

In three out of eight cases, these echogenic nodular foci were associated with other cerebral findings. In two cases (cases 1 and 2), 5-10 echogenic nodular foci were found at US examination performed at 33 and 34 weeks, respectively. In both cases, abnormal echogenicity and thickening of the germinal matrix were observed below the frontal horns at US examination (fig. 2). In case 1, an echogenic lesion of the left thalamus was also observed (fig. 3). No additional cerebral anomalies were found at MRI. In the third case (case 7), multiple echogenic nodular foci were observed throughout the cerebral brain at 31 weeks. Multiple echogenic areas of the white matter were present in the subcortical, periaqueductal and periventricular regions. MRI examination confirmed multiple lesions of the fetal brain and TOP was performed at 33 weeks. 
Table 1. Description of the nine cases of congenital toxoplasmosis infection

\begin{tabular}{|c|c|c|c|c|c|c|c|c|}
\hline $\begin{array}{l}\text { Case } \\
\text { No. }\end{array}$ & $\begin{array}{l}\text { GA at } \\
\text { maternal } \\
\text { infection }\end{array}$ & $\begin{array}{l}\text { GA at PCR } \\
\text { pos. for } \\
T \text {. gondii }\end{array}$ & $\begin{array}{l}\text { GA at } \\
\text { treatment } \\
\text { onset }\end{array}$ & $\begin{array}{l}\text { GA at } \\
\text { abnormal } \\
\text { cerebral } \\
\text { findings }\end{array}$ & $\begin{array}{l}\text { Prenatal cerebral } \\
\text { findings }\end{array}$ & $\begin{array}{l}\text { Prenatal } \\
\text { extracerebral } \\
\text { findings }\end{array}$ & $\begin{array}{l}\text { Biometrics } \\
\text { at birth: } \\
\text { GA, BW, HC }\end{array}$ & Postnatal findings \\
\hline 1 & $22-27$ & $31+1$ & $31+4$ & $33+0$ & $\begin{array}{l}5-10 \text { parenchymal } \\
\text { nodular foci; } 1 \text { thalamic } \\
\text { nodular focus; bilateral } \\
\text { hyperechogenicity of the } \\
\text { germinal matrix (frontal } \\
\text { horns); no ventriculo- } \\
\text { megaly; MRI ( } 34 \text { WG): } \\
\text { same aspect }\end{array}$ & $\begin{array}{l}\text { fetomaternal } \\
\text { hemorrhage ( } 31 \mathrm{WG);} \\
\text { intrauterine transfusion } \\
\text { ( } 32 \mathrm{WG);} \mathrm{hepatospleno-} \\
\text { megaly ( } 33 \mathrm{WG)}\end{array}$ & $\begin{array}{l}37+0 \\
3,445 \mathrm{~g} \\
34 \mathrm{~cm}\end{array}$ & $\begin{array}{l}\text { Transfontanellar US: same aspect } \\
\text { MRI ( } 1 \text { month): stability of the thalamic foci, } \\
\text { hyposignal in T1, hypersignal in T2, moderate } \\
\text { increase of diffusion coefficient in the subcortical } \\
\text { white matter } \\
\text { Neurodevelopmental delay: none } \\
\text { Fundus oculi exam (10 months): left temporal } \\
\text { peripheral retinochoroiditis } \\
\text { Visual sequela: no visual impairment } \\
\text { Postnatal regimen: pyrimethamine + sulfadoxine } \\
\text { (12 months) } \\
\text { Follow-up: } 15 \text { months }\end{array}$ \\
\hline 2 & $22-27$ & $33+3$ & $34+3$ & $34+4$ & $\begin{array}{l}7 \text { parenchymal nodular } \\
\text { foci; bilateral hyperecho- } \\
\text { genicity of the germinal } \\
\text { matrix (frontal horns); no } \\
\text { ventriculomegaly; MRI } \\
\text { ( } 35 \mathrm{WG):} \mathrm{same} \mathrm{aspect}\end{array}$ & $\begin{array}{l}\text { hepatomegaly } \\
(35+4 \mathrm{WG})\end{array}$ & $\begin{array}{l}39+5 \\
3,380 \mathrm{~g} \\
34 \mathrm{~cm}\end{array}$ & $\begin{array}{l}\text { Transfontanellar US: bilateral cysts of the germinal } \\
\text { matrix, same foci as those described during the } \\
\text { prenatal period } \\
\text { Neurodevelopmental delay: none } \\
\text { Fundus oculi exam (1 month): right macular } \\
\text { retinochoroiditis } \\
\text { Visual sequela: significantly impaired vision of the } \\
\text { right eye } \\
\text { Postnatal regimen: pyrimethamine + sulfadoxine } \\
\text { (12 months) } \\
\text { Follow-up: } 36 \text { months }\end{array}$ \\
\hline 3 & $10-18$ & $*$ & $24+0$ & $23+6$ & $\begin{array}{l}3 \text { parenchymal nodular } \\
\text { foci; no ventriculomegaly; } \\
\text { MRI ( } 31 \text { WG): normal }\end{array}$ & - & $\begin{array}{l}41+0 \\
3,530 \mathrm{~g} \\
35 \mathrm{~cm}\end{array}$ & $\begin{array}{l}\text { Transfontanellar US: } 4 \text { foci ( } 1 \text { left frontal, } 2 \text { left } \\
\text { parietotemporal, } 1 \text { right temporal) } \\
\text { Neurodevelopmental delay: none } \\
\text { Fundus oculi exam (first year): right macular } \\
\text { retinochoroiditis } \\
\text { Visual sequela: amblyopia of the right eye } \\
\text { Postnatal regimen: pyrimethamine + sulfadoxine } \\
\text { (12 months) } \\
\text { Follow-up: } 36 \text { months }\end{array}$ \\
\hline 4 & $11-20$ & $25+0$ & $25+0$ & $29+0$ & $\begin{array}{l}2 \text { parenchymal nodular } \\
\text { foci; no ventriculomegaly; } \\
\text { MRI ( } 31 \text { WG): normal }\end{array}$ & - & $\begin{array}{l}34+4 \\
2,460 \mathrm{~g} \\
33 \mathrm{~cm}\end{array}$ & $\begin{array}{l}\text { Transfontanellar US: } 3 \text { foci } \\
\text { MRI (15 days): } 8 \text { foci of small sizes ( } 2 \text { left } \\
\text { temporal, } 1 \text { occipital, } 3 \text { left frontal, } 1 \text { right frontal, } \\
1 \text { periventricular near the right atrium) } \\
\text { Neurodevelopmental delay: none } \\
\text { Fundus oculi exam: normal } \\
\text { Visual sequela: no visual impairment } \\
\text { Postnatal regimen: pyrimethamine + sulfadoxine } \\
\text { (12 months) } \\
\text { Follow-up: } 36 \text { months }\end{array}$ \\
\hline 5 & $20-24$ & $28+5$ & $29+0$ & $31+4$ & $\begin{array}{l}<5 \text { parenchymal nodular } \\
\text { foci; no ventriculomegaly; } \\
\text { MRI ( } 31+5 \text { WG): } \\
3 \text { parenchymal foci }\end{array}$ & - & $\begin{array}{l}39+2 \\
3,200 \mathrm{~g} \\
33 \mathrm{~cm}\end{array}$ & $\begin{array}{l}\text { Transfontanellar US: n.a. } \\
\text { Neurodevelopmental delay: none } \\
\text { Fundus oculi exam: right side } 2 \text { foci of } \\
\text { retinochoroiditis ( } 1 \text { bordering the macula), left } \\
\text { side } 2 \text { peripheral foci } \\
\text { Visual sequela: no visual impairment } \\
\text { Postnatal regimen: pyrimethamine + sulfadoxine } \\
\text { (12 months) } \\
\text { Follow-up: } 12 \text { months }\end{array}$ \\
\hline 6 & $14-20$ & $26+5$ & $27+2$ & $31+5$ & $\begin{array}{l}1 \text { parenchymal focus; } \\
2 \text { additional parenchymal } \\
\text { foci at } 36 \text { WG; no } \\
\text { ventriculomegaly }\end{array}$ & $\begin{array}{l}\text { rhizomelic shortening of } \\
\text { long bones at } 32 \mathrm{WG} \\
\text { with subsequently } \\
\text { maintained growth }\end{array}$ & $\begin{array}{l}39+0 \\
2,905 \mathrm{~g} \\
35 \mathrm{~cm}\end{array}$ & $\begin{array}{l}\text { Transfontanellar US: } 5 \text { foci (1 right frontal, } 2 \text { right } \\
\text { parietal, } 2 \text { left parietal) } \\
\text { Neurodevelopmental delay: none } \\
\text { Fundus oculi exam: normal } \\
\text { Visual sequela: no visual impairment } \\
\text { Postnatal regimen: pyrimethamine + sulfadoxine } \\
\text { (12 months) } \\
\text { Follow-up: } 24 \text { months }\end{array}$ \\
\hline 7 & 19 & $32+2$ & - & $31+0$ & $\begin{array}{l}10 \text { parenchymal nodular } \\
\text { foci; extensive echogenic } \\
\text { areas of the white matter in } \\
\text { subcortical, periaqueductal } \\
\text { and periventricular } \\
\text { regions; no ventriculo- } \\
\text { megaly; MRI ( } 32 \mathrm{WG):} \\
\text { same aspect }\end{array}$ & $\begin{array}{l}\text { hepatosplenomegaly } \\
\text { (31 WG) }\end{array}$ & $\begin{array}{l}\text { TOP } \\
33+4 \\
2,240 \mathrm{~g} \\
31 \mathrm{~cm}\end{array}$ & $\begin{array}{l}\text { Pathological findings: hepatosplenomegaly; } \\
\text { pulmonary lesions (necrosis and toxoplasmic } \\
\text { cysts); multiple and extensive lesions in cerebral } \\
\text { parenchyma (necrosis and toxoplasmic cysts) }\end{array}$ \\
\hline
\end{tabular}


Table 1 (continued)

\begin{tabular}{|c|c|c|c|c|c|c|c|c|}
\hline $\begin{array}{l}\text { Case } \\
\text { No. }\end{array}$ & $\begin{array}{l}\text { GA at } \\
\text { maternal } \\
\text { infection }\end{array}$ & $\begin{array}{l}\text { GA at PCR } \\
\text { pos. for } \\
\text { T. gondii }\end{array}$ & $\begin{array}{l}\text { GA at } \\
\text { treatment } \\
\text { onset }\end{array}$ & $\begin{array}{l}\text { GA at } \\
\text { abnormal } \\
\text { cerebral } \\
\text { findings }\end{array}$ & $\begin{array}{l}\text { Prenatal cerebral } \\
\text { findings }\end{array}$ & $\begin{array}{l}\text { Prenatal } \\
\text { extracerebral } \\
\text { findings }\end{array}$ & $\begin{array}{l}\text { Biometrics } \\
\text { at birth: } \\
\text { GA, BW, HC }\end{array}$ & Postnatal findings \\
\hline 8 & $<22$ & $26+4$ & $28+0$ & $26+0$ & $\begin{array}{l}10 \text { parenchymal nodular } \\
\text { foci; no ventriculomegaly }\end{array}$ & - & $\begin{array}{l}\text { TOP } \\
31+5 \\
1,811 \mathrm{~g} \\
28 \mathrm{~cm}\end{array}$ & $\begin{array}{l}\text { Pathological findings: cerebral findings (multiple } \\
\text { limited cortical lesions of necrosis with diffuse } \\
\text { vasculitis lesions); no extracerebral findings }\end{array}$ \\
\hline 9 & $<30$ & $31+1$ & - & $32+5$ & $\begin{array}{l}\text { multiple parenchymal } \\
\text { nodular foci; no } \\
\text { ventriculomegaly }\end{array}$ & $\begin{array}{l}\text { severe fetal hydrops at } \\
32 \text { WG: fetal anemia and } \\
\text { toxoplasmic fetopathy }\end{array}$ & $\begin{array}{l}\text { TOP } \\
34+0 \\
2,280 \mathrm{~g} \\
32 \mathrm{~cm}\end{array}$ & $\begin{array}{l}\text { Pathological findings: toxoplasmic fetopathy with } \\
\text { multivisceral involvement: interstitial } \\
\text { mononuclear infiltrates in the lung, kidneys, } \\
\text { myocardium, bowel and liver; cerebral findings: } \\
\text { diffuse lesions of vasculitis associated with } \\
\text { multiple limited lesions of necrosis disseminated } \\
\text { in the periventricular white matter, foci } \\
\text { surrounded by inflammatory lesions and } \\
\text { calcifications }\end{array}$ \\
\hline
\end{tabular}

$\mathrm{BW}=$ Birth weight; $\mathrm{GA}=$ gestational age; $\mathrm{HC}=$ head circumference; $n$. . . = not available; $\mathrm{WG}=$ weeks gestation.

* Amniotic fluid sampling declined by the patient.

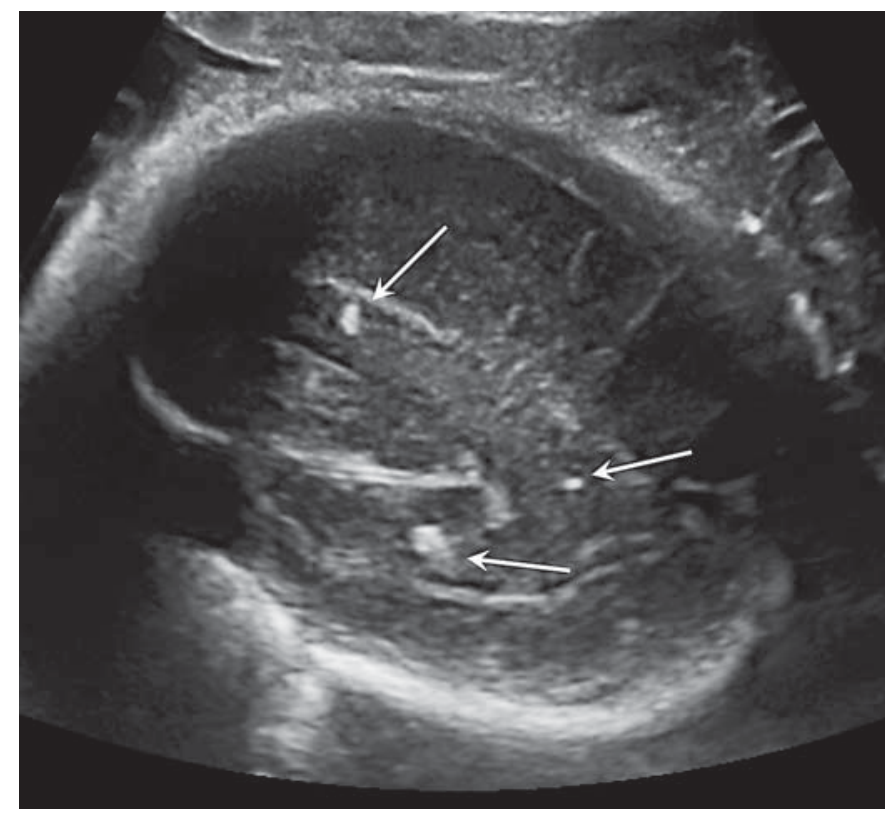

Fig. 1. US parasagittal view of the fetal brain at 34 weeks. Multiple echogenic nodular foci are disseminated in the cerebral parenchyma (arrows).

In the other five cases (cases 3, 4, 5, 6 and 8), echogenic nodular foci were isolated. In one case, TOP was performed at 30 weeks within the context of severe maternal schizophrenia (case 8).

\section{Pregnancy and Neonatal Outcomes}

Postmortem examinations were performed in all three cases where patients opted for TOP. In case 9, several in- terstitial mononuclear infiltrates were observed at histological examination of the lung, kidneys and myocardium. Examination of the brain revealed diffuse lesions of vasculitis associated with multiple limited lesions of necrosis disseminated in the periventricular white matter. These necrotic foci were surrounded by inflammatory lesions and calcifications. In case 8 , brain examination confirmed multiple limited cortical lesions of necrosis with diffuse vasculitis lesions. In case 7, postmortem examination revealed hepatosplenomegaly and multiple specific lesions of toxoplasmosis in the lung tissues. Multiple extensive lesions of cerebral necrosis were observed at neuropathological examination.

In all six living children, neurological development is normal at 1-3 years of age. Two infants present visual impairment: amblyopia of one eye in case 3, low vision of one eye due to a large macular retinochoroiditis lesion in case 2 . The bilateral vision of the other four children is normal (peripheral retinochoroiditis lesions found at ocular fundus in two out of four).

\section{Discussion}

Our results demonstrate the importance of closely monitoring the fetal cerebral anatomy in cases of proven and treated fetal infection with T. gondii. Moreover, they emphasize the need to carefully examine the brain parenchyma, including in cases where no ventriculomegaly is noted. The majority of our cases were related to a secondtrimester maternal infection and the cerebral anomalies were detected several weeks later, until 34 weeks. This 


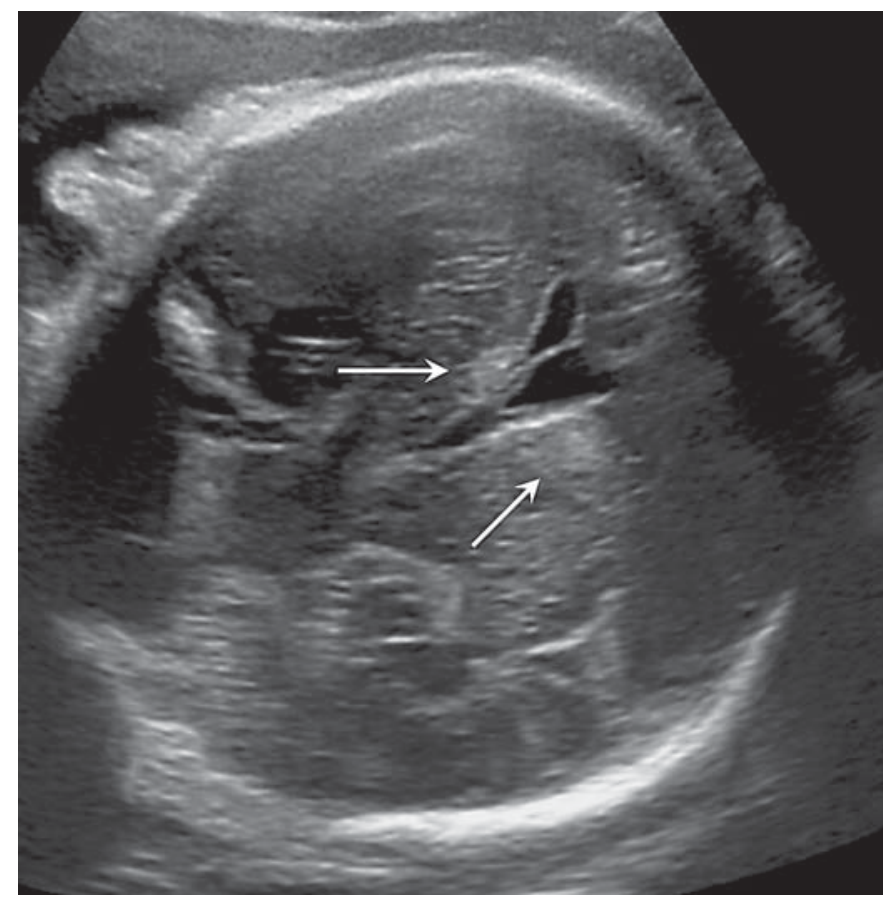

Fig. 2. US anterior coronal view of the fetal brain at $31+3$ weeks. Abnormal echogenicity and thickening of the germinal matrix are observed below the frontal horns (arrows).

long period of time between the onset of fetal infection and the appearance of the first anomalies of the fetal brain has already been reported [4]. This observation makes it essential to continue monitoring these cases until the end of pregnancy.

The majority of studies on congenital toxoplasmosis have focused on the justification of a screening policy in pregnant women [6] and the potential benefit of prenatal treatment $[2,3]$. These two questions still remain very controversial. Surprisingly, only few reports on cerebral US findings in case of fetal infection have been reported $[3,7-11]$. Whatever the recommendation on systematic maternal serum screening across different countries, we consider that the cerebral signs associated with congenital toxoplasmosis should be more largely diffused. Except for cases of significant ventricular dilation, very few studies have focused on fetal cerebral signs in congenital toxoplasmosis [3, 7-11]. Yet, a better knowledge of these signs would be of interest as fetal prognosis largely depends on the severity of the cerebral damage.

Cerebral calcifications in children with congenital toxoplasmosis are observed in $5-9 \%$ of cases $[12,13]$. The presence of these cerebral calcifications is considered a risk factor for the development of retinochoroidi-

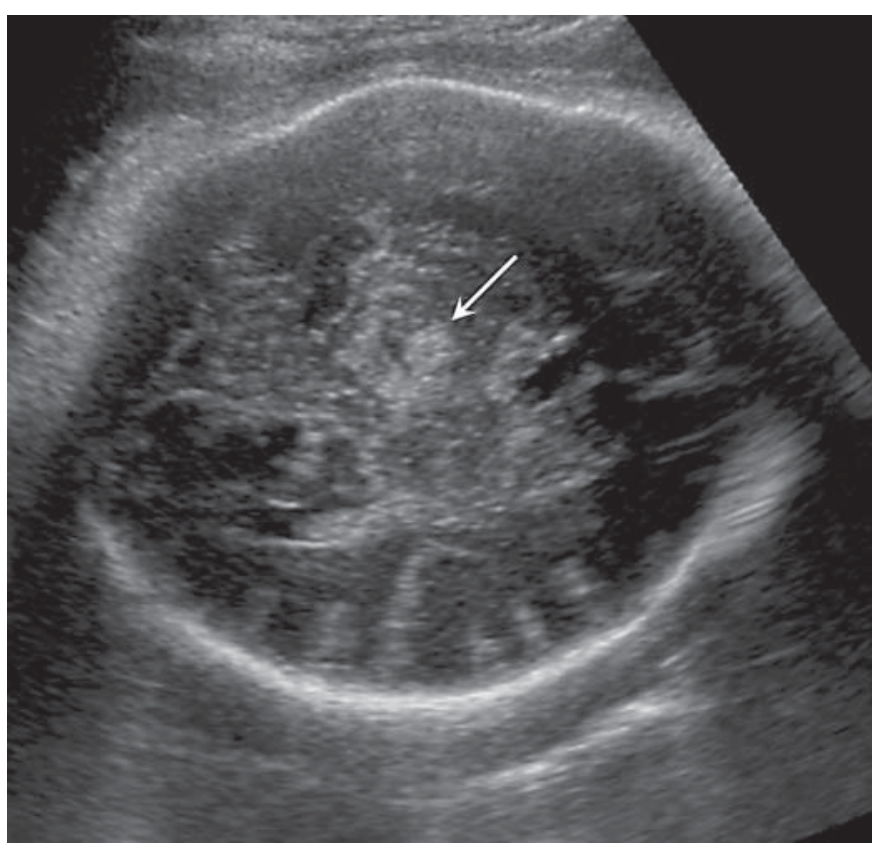

Fig. 3. US axial slice of the fetal brain at 34 weeks. An echogenic lesion of the left thalamus is seen (arrow).

tis during childhood [12]. To the best of our knowledge, the association between these calcifications and the neurodevelopment of the children has not yet been specifically assessed. In the prenatal period, cerebral hyperechogenic foci have been described in case of congenital toxoplasmosis, but most often associated with ventriculomegaly, making it difficult to evaluate their specific impact on future neurological development $[7,8]$. Some authors described them as 'calcification' by analogy with the images of calcifications that may be observed later on in life on skull radiographs of patients with neurological impairment [11]. These echogenic cerebral lesions were found postnatally in all our cases. The results from the postmortem examinations of our terminated cases may suggest that these echogenic lesions correspond to limited areas of cerebral necrosis, as previously suggested by Hohlfeld et al. [10]. However, conversely to their statement, our results may suggest that the neurodevelopmental outcome may be favorable when these lesions are isolated in the prenatal period. Only one case of prenatal diagnosis of isolated cerebral echogenic nodular foci with no ventriculomegaly has been reported by Malinger et al. [11], who suggested that in these circumstances, neurological outcome may favorable. However, our re- 
sults should be interpreted with caution due to the limited number of cases and the relative young age of the children. We also acknowledge that the retrospective design of our series of cases is potentially subject to selection bias. However, one strength of our study is represented by the fact that one single pediatrician clinically evaluated all these infants. It will be of great interest to continue monitoring the neurodevelopment of these children in the future.

In our study we found three cases with associated cerebral findings (cases 1, 2 and 7). In two cases an abnormal echogenic aspect was limited to the germinal matrix adjacent to the frontal horns (cases 1 and 2). The neurological outcome was normal in these two cases. Interestingly, this aspect is similar to the one described within the context of fetal cytomegalovirus infection [14]. In the third case, the associated findings consisted of extensive white matter anomalies leading to TOP, and the postmortem examination confirmed the presence of multiple large areas of cerebral necrosis (case 7). In our series, the contribution of MRI to the characterization of the cases was limited. This confirms the good correlation between US and MRI in the diagnosis of fetal brain anomalies in congenital toxoplasmosis [15].

Beside the neurological prognosis, the other major goal of prenatal diagnosis in cases of fetal toxoplasmosis infection is to minimize ocular damage by offering early specific treatment. Among the six fetuses (cases 1-6) with echoic parenchymal cerebral nodules, four were diagnosed postnatally with retinochoroiditis lesions (cases 1,
2, 3 and 5). The ocular damage was severe in one case with unilateral amblyopia (case 3) and moderate in another case with a unilateral macular lesion (case 2). We observed a higher proportion of ocular damage than previously reported in series of infected fetuses with normal prenatal US findings $[1,16-18]$. In the postnatal period, the presence of cerebral calcifications is associated with an increased risk of retinochoroiditis during the first 2 years in infants treated for congenital toxoplasmosis (4fold increased risk) [12]. In the same way, the presence of cerebral echogenic foci in the prenatal period may be associated with a higher risk of ocular lesions.

In conclusion, if fetal T. gondii infection is detected during pregnancy and treatment is initiated, a third-trimester and follow-up scans should be performed looking for calcifications, ventricular dilation and hydrops. In case of strictly isolated calcifications, the prognosis may be favorable, although there remains an increased risk of ocular damage, which is not accessible to prenatal diagnosis.

\section{Statement of Ethics}

Oral informed consent was obtained from the patients.

\section{Disclosure Statement}

The authors have no conflicts of interest to disclose. There were no funding sources.

\section{References}

1 Wallon M, Garweg JG, Abrahamowicz M, Cornu C, Vinault S, Quantin C, BonithonKopp C, Picot S, Peyron F, Binquet C: Ophthalmic outcomes of congenital toxoplasmosis followed until adolescence. Pediatrics 2014;133:e601-e608.

2 SYROCOT (Systematic Review on Congenital Toxoplasmosis) study group, Thiebaut $\mathrm{R}$, Leproust S, Chene G, Gilbert R: Effectiveness of prenatal treatment for congenital toxoplasmosis: a meta-analysis of individual patients' data. Lancet 2007;369:115-122.

3 Gras L, Gilbert RE, Ades AE, Dunn DT: Effect of prenatal treatment on the risk of intracranial and ocular lesions in children with congenital toxoplasmosis. Int J Epidemiol 2001; 30:1309-1313.

4 Jacquemard F: Ultrasonographic signs of congenital toxoplasmosis (in French). Arch Pediatr 2003;10(suppl 1):35-38.
5 McLeod R, Boyer K, Karrison T, Kasza K, Swisher C, Roizen N, Jalbrzikowski J, Remington J, Heydemann P, Noble AG, Mets M, Holfels E, Withers S, Latkany P, Meier P; Toxoplasmosis Study Group: Outcome of treatment for congenital toxoplasmosis, 1981-2004: the National Collaborative Chicago-Based, Congenital Toxoplasmosis Study. Clin Infect Dis 2006;42:1383-1394.

6 Wallon M, Peyron F, Cornu C, Vinault S, Abrahamowicz M, Kopp CB, Binquet C: Congenital Toxoplasma infection: monthly prenatal screening decreases transmission rate and improves clinical outcome at age 3 years. Clin Infect Dis 2013;56:1223-1231.
7 di Carlo P, Romano A, Casuccio A, Cillino S, Schimmenti MG, Mancuso G, la Chiusa S, Novara V, Ingrassia D, Li Vecchi V, Trizzino $\mathrm{M}$, Titone L: Investigation and management of Toxoplasma gondii infection in pregnancy and infancy: a prospective study. Acta Pharmacol Sin 2011;32:1063-1070.

8 Friedman S, Ford-Jones LE, Toi A, Ryan G, Blaser S, Chitayat D: Congenital toxoplasmosis: prenatal diagnosis, treatment and postnatal outcome. Prenat Diagn 1999;19:330-333.

9 Guerina NG, Hsu HW, Meissner HC, Maguire JH, Lynfield R, Stechenberg B, Abroms I, Pasternack MS, Hoff R, Eaton RB, et al: Neonatal serologic screening and early treatment for congenital Toxoplasma gondii infection. The New England Regional Toxoplasma Working Group. N Engl J Med 1994;330: 1858-1863.
Fetal Parenchymal Cerebral Lesions in Congenital Toxoplasmosis Infection 
10 Hohlfeld P, MacAleese J, Capella-Pavlovski M, Giovangrandi Y, Thulliez P, Forestier F, Daffos F: Fetal toxoplasmosis: ultrasonographic signs. Ultrasound Obstet Gynecol 1991;1:241-244.

11 Malinger G, Werner H, Rodriguez Leonel JC, Rebolledo M, Duque M, Mizyrycki S, Lerman-Sagie T, Herrera M: Prenatal brain imaging in congenital toxoplasmosis. Prenat Diagn 2011;31:881-886.

12 Kieffer F, Wallon M, Garcia P, Thulliez P, Peyron F, Franck J: Risk factors for retinochoroiditis during the first 2 years of life in infants with treated congenital toxoplasmosis. Pediatr Infect Dis J 2008;27:27-32.
13 Kodjikian L, Wallon M, Fleury J, Denis P, Binquet C, Peyron F, Garweg JG: Ocular manifestations in congenital toxoplasmosis. Graefes Arch Clin Exp Ophthalmol 2006;244:1421.

14 Picone O, Teissier N, Cordier AG, VauloupFellous C, Adle-Biassette H, Martinovic J, Senat MV, Ayoubi JM, Benachi A: Detailed in utero ultrasound description of 30 cases of congenital cytomegalovirus infection. Prenat Diagn 2014;34:518-524.

15 Blondiaux E, Garel C: Fetal cerebral imaging - ultrasound vs. MRI: an update. Acta Radiol 2013;54:1046-1054.

16 Berrebi A, Assouline C, Bessieres MH, Lathiere M, Cassaing S, Minville V, Ayoubi JM: Long-term outcome of children with congenital toxoplasmosis. Am J Obstet Gynecol 2010;203:552.e1-552.e6.
17 Berrebi A, Bardou M, Bessieres MH, Nowakowska D, Castagno R, Rolland M, Wallon M, Franck J, Bongain A, Monnier-Barbarino P, Assouline C, Cassaing S: Outcome for children infected with congenital toxoplasmosis in the first trimester and with normal ultrasound findings: a study of 36 cases. Eur J Obstet Gynecol Reprod Biol 2007;135:53-57.

18 Binquet C, Wallon M, Quantin C, Kodjikian L, Garweg J, Fleury J, Peyron F, Abrahamowicz M: Prognostic factors for the long-term development of ocular lesions in 327 children with congenital toxoplasmosis. Epidemiol Infect 2003; 131:1157-1168. 